\title{
Tetracycline-regulated secretion of human insulin in a transfected non-endocrine cell line
}

\author{
K T Scougall, C A Maltin ${ }^{1}$ and J A M Shaw \\ Department of Medicine and Therapeutics, University of Aberdeen, Institute of Medical Sciences, Foresterhill, Aberdeen, UK and ${ }^{1}$ Rowett Research \\ Institute, Greenburn Road, Bucksburn, Aberdeen, UK \\ (Requests for offprints should be addressed to J A M Shaw, Department of Diabetes and Metabolism, School of Clinical Medical Sciences, University \\ of Newcastle upon Tyne, Framlington Place, Newcastle upon Tyne NE2 4HH, UK; Email: jim.shaw@ncl.ac.uk)
}

\begin{abstract}
Long-term constitutive secretion of insulin by implantation of ex vivo transfected cells such as fibroblasts or myoblasts or in situ by intramuscular injection of naked plasmid DNA provides a potential approach to gene therapy for diabetes mellitus. A mechanism for regulating insulin secretion will be necessary to realize the therapeutic potential of this approach. A second obstacle is the inability of non-endocrine host cells to fully process proinsulin. Therefore, alteration of the wild-type cDNA will be necessary to achieve processing of proinsulin by endogenous endoproteases within these cells. The cDNAs for $\beta$-galactosidase ( $\beta$ ), human wild-type proinsulin (hppl1) and a mutated construct (hppl4), in which the dibasic PC2 and PC3 cleavage sites had been altered to form furin cleavage sites, were sub-cloned into four vectors ( $p C R 3$, pVR1012, pIRES, pTRE), including a tetracycline responsive plasmid ( $p$ TRE) that requires co-transfection with another plasmid encoding a transactivator (pTet-off) for transgene expression. Transient transfection of the COS-7 fibroblast cell line with these constructs was performed using DEAE-dextran and liposomes. Analysis of vector efficiencies revealed that pTRE/pTetoff $>$ pIRES $>$ pCR3 $>$ pVR1012. Further analysis demonstrated total pro/insulin secretion of $2.33 \mathrm{ng} / 10^{6}$ cells $/ 24 \mathrm{~h}$ with $\geq 25 \%$ processed to insulin in hppl-1.pTRE/pTet-off-transfected cells compared with $0.39 \mathrm{ng} / 10^{6}$ cells $/ 24 \mathrm{~h}$ and $>70 \%$ processing in hppl-4.pTRE/pTet-off-transfected cells. In co-transfection studies with pTRE-hppl1/pTet-off and pTRE-hppl4/pTet-off constructs, pro/insulin secretion was inhibited to $65-66 \%$ and $36-38 \%$ of control $(100 \%)$ in the presence of 0.01 and $0.1 \mu \mathrm{g} / \mathrm{ml}$ tetracycline respectively over a 24-h incubation period. Furthermore, reversal of tetracycline inhibition was demonstrated for pTRE-hppl1/pTet-off- and pTRE-hppl4/pTet-off-transfected cells. After a 48-h incubation with $1.0 \mu \mathrm{g} / \mathrm{ml}$ tetracycline, total pro/insulin levels were 10 and $14 \%$ compared with untreated cells respectively. On tetracycline removal, total proinsulin levels increased and were equivalent to untreated groups $72 \mathrm{~h}$ later. In conclusion, regulation of fully processed human insulin secretion has been achieved in a transiently transfected non-endocrine cell line.
\end{abstract}

Journal of Molecular Endocrinology (2003) 30, 331-346

\section{Introduction}

Transfer of genes encoding therapeutic proteins into accessible somatic cell may lead to new potential treatments for a broad range of diseases (MacColl et al. 1999, Spirito et al. 2001). Host fibroblasts or myoblasts can be derived from minimally invasive biopsies, transfected ex vivo and implanted, thereby avoiding the need for immunosuppression. In addition, transgenes can be expressed in host skeletal muscle in situ follow- ing intramuscular injection of viral vectors or plasmid DNA (Wells 1995, van Deutekom et al. 1998).

Host-derived fibroblasts have been considered for growth hormone delivery (Heartlein et al. 1994) and insulin replacement in diabetes (Kawakami et al. 1992, Taniguchi et al. 1997, Falqui et al. 1999). Constitutive secretion of fully processed human insulin was attained in transfected fibroblasts using a preproinsulin construct in which PC2 and PC3 cleavage sites were altered to allow furin 
recognition (Falqui et al. 1999). In vivo studies in rodents were, however, complicated by hypoglycaemia due to unregulated cell proliferation, leading to increased insulin secretion (Falqui et al. 1999). Prolonged systemic secretion at therapeutically active concentrations of proteins including growth hormone (Dhawan et al. 1991), factor IX (Hortelano et al. 2001) and $\alpha 1$ antitrypsin (Bou-Gharios et al. 1999) has been demonstrated in transfected myoblasts following implantation in rodent muscle.

In vivo gene transfer to muscle can mediate transgene expression for up to 19 months (Wolff et al. 1992). This approach has been evaluated for DNA vaccination (Brower 1998), cytokine delivery (Prud'homme 2000) and treatment of heart disease (Teiger et al. 2001), in addition to erythropoietin (Tripathy et al. 1996), growth hormone (Rivera et al. 1999) and leptin replacement (Murphy et al. 1997). Constitutive secretion of processed human insulin has been demonstrated for up to 5 weeks in rodents following simple intramuscular injection with a preproinsulin plasmid modified for furin recognition (Abai et al. 1999, Kon et al. 1999, Shaw et al. 2002). Sustained glucose lowering was demonstrated without dangerous hypoglycaemia (Shaw et al. 2002). In individuals with haemophilia B, factor IX has been successfully expressed in muscle following injection with an adenoassociated viral vector containing the transgene (High 2001).

Plasmid DNA for ex vivo or in vivo therapeutic gene transfer has several advantages in comparison with viral vectors. These include relative ease of production on a large scale, cost-efficiency, lower toxicity and decreased immunogenicity. Although transgene expression remains comparatively low, there is considerable ongoing research addressing novel delivery methods to maximise plasmid uptake and retention together with plasmid modifications to optimise mRNA expression and stability (Xu et al. 2001, Liu \& Huang 2002).

A mechanism for safely regulating constitutive secretion following plasmid-mediated transfection, and more specifically for 'turning down' transgene protein levels, would greatly enhance the applicability of this approach for therapeutic use. This will be particularly important for insulin replacement in diabetes, allowing titration of a constant background level of insulin between meals and a mechanism for averting dangerous hypoglycaemia.
Several small molecule transcriptional regulatory systems have been developed including those based on tetracycline (Gossen \& Bujard 1992), FK506/rapamycin (Rivera et al. 1996), RU486/ progesterone (Wang et al. 1994) and ecdysone (No et al. 1996). These small molecules reversibly bind to modified transcription factors inducing or repressing transcription of a transgene. The tetracycline system has several advantages: (1) tetracycline, an antibiotic, has been well characterised for clinical use, (2) the doses required to regulate transcription are not toxic, (3) the integral regulatory elements employed are prokaryotic and will not interfere with host mammalian transcription machinery (Blau \& Rossi 1999) and (4) efficient regulation of reporter gene expression has been demonstrated following plasmid-mediated gene transfer to muscle in vivo (Dhawan et al. 1995).

The objective of these studies was to evaluate the potential for tetracycline-regulated secretion of fully processed human insulin, following transient transfection of the non-endocrine COS-7 fibroblast cell line. Initially, efficiency of transgene uptake and expression employing a range of plasmids under the control of a constitutive cytomegalovirus or tetracycline repressible promoter were compared using a $\beta$-galactosidase reporter gene and a wild-type human preproinsulin gene. Thereafter, proinsulin synthesis, processing and secretion together with the potential for tetracycline transcriptional regulation were evaluated using a wild-type preproinsulin plasmid and a mutant plasmid modified to enable cleavage by furin.

\section{Materials and methods}

Cell culture reagents were purchased from Invitrogen Ltd (Paisley, UK) and chemicals were purchased from Sigma-Aldrich Company Ltd (Poole, Dorset, UK) and BDH (Poole, Dorset, UK) unless otherwise stated. Restriction and DNA modification enzymes were purchased from Promega (Southampton, UK). Plasmids pIRES, pTRE, pTet-off and CMV- $\beta$ were obtained from CLONTEGH Laboratories Ltd (Basingstoke, Hants, UK), pCR3 from Invitrogen Ltd and pVR1012 from Vical Inc (San Diego, CA, USA). The monkey kidney fibroblast, COS-7 cell line was a gift from Prof. A Rees, University of Aberdeen, UK. 


\section{Expression plasmids}

The mammalian expression vectors used in this study are described in Table 1. For eukaryotic transgene expression, all plasmids consisted of the human cytomegalovirus (CMV) enhancer/ promoter, with the exception of tetracycline responsive plasmid (pTRE). For transgene polyadenylation and transcriptional termination, bovine growth hormone $(\mathrm{BGH})$ or simian virus 40 (SV40) sequences were employed. Genes encoding either ampicillin or kanamycin resistance were used for bacterial selection. All plasmids contained the neomycin phosphotransferase gene for mammalian selection, with the exception of pTRE, which has no selectable marker. Plasmid pCR3 has been optimised to remove potential RNA secondary structure sequences (Mizushima \& Nagata 1990). Plasmid pIRES has been modified to possess an internal ribosomal entry sequence which permits translation of two open reading frames from one messenger RNA and a synthetic intron known to enhance the stability of mRNA (Rees et al. 1996). Plasmid pVR1012 has been optimised for enhanced transgene expression (Hartikka et al. 1996). The tetracycline transcriptional regulatory system (Gossen \& Bujard 1992) requires co-transfection with pTRE and pTet-off plasmids. Plasmid pTet-off encodes a transactivator (VP16/TetR) that binds reversibly to the tetracycline responsive element $(7$ copies of a $42 \mathrm{bp}$ sequence of the tet operator (tetO) fused upstream of a minimal CMV promoter) within pTRE, initiating transcription. In the presence of tetracycline, binding of the transactivator protein is inhibited, blocking gene transcription. Transgene expression can be regulated, as binding of tetracycline is both reversible and dose-responsive.

\section{Plasmid construction}

Wild-type (hppIl) and mutant (hppI4, in which the PC2 and PC3 dibasic cleavage sites have been mutated to furin consensus cleavage sites) human preproinsulin cDNAs have been described previously (Shaw et al. 2002) and were available as inserts in pCR3 (pCR3-hppIl and pCR3-hppI4) and pIRES (pIRES-hppIl and pIRES-hppI4). Wild-type and mutant insulin cDNAs were ligated into pTRE using EcoRI sites to give pTRE-hppIl and pTRE-hppI4 respectively. Inserts were sub- cloned as EcoRI fragments into pCR3. Inserts incorrectly orientated were cleaved using BamHI and $\mathrm{XbaI}$ and sub-cloned into BamHI/XbaI digested pVR1012 to give correctly orientated inserts pVR1012-hppI 1 and pVR1012-hppI4. The $\beta$-galactosidase gene was excised from construct CMV- $\beta$ by NotI digestion and sub-cloned as a NotI fragment into pCR3 and pIRES (pCR3- $\beta$, pIRES- $\beta$ ). Following pCR3- $\beta$ digestion with EcoRI/XbaI and Pst/XbaI, the $\beta$-galactosidase insert was sub-cloned into equivalent digested pTRE and pVR1012 respectively (pTRE- $\beta$, pVR1012- $\beta$ ). All constructs were characterised by restriction digests and purified by QIAGEN DNA columns (QIAGEN Ltd, Crawley, West Sussex, UK).

\section{Cell cultures}

COS-7 cells were maintained in growth medium consisting of Dulbecco's modified Eagles's medium (DMEM) supplemented with 10\% (v/v) heat inactivated fetal calf serum (FCS), penicillin G $(100 \mathrm{U} / \mathrm{ml})$, streptomycin $(100 \mu \mathrm{g} / \mathrm{ml})$, and cultured in a humidified atmosphere of $5 \% \mathrm{CO}_{2} / 95 \%$ air at $37^{\circ} \mathrm{C}$.

\section{Transfections}

Transient transfections were performed with DEAE-dextran (Amersham-Pharmacia plc, Little Chalfont, Bucks, UK) using previously described protocols (Luthman \& Magnusson 1983, Lopata et al. 1984) or with cationic lipsomes, TransFast, purchased from Promega. COS-7 cells were transfected at $70-80 \%$ confluence in 6-well plates (diameter $3.5 \mathrm{~cm} /$ well). Each well was transfected using $2 \mu \mathrm{g}$ of each cDNA, $1 \mathrm{mg} / \mathrm{ml}$ DEAEdextran/PBS in a final volume of $200 \mu$ l Hank's balanced salt solution and incubated on cells for 20 min at $37{ }^{\circ} \mathrm{C} / 5 \% \mathrm{CO}_{2}$, with gentle agitation every $10 \mathrm{~min}$. Growth medium (1 ml) supplemented with chloroquine $(100 \mu \mathrm{M})$ was added and the cells incubated at $37{ }^{\circ} \mathrm{C} / 5 \% \mathrm{CO}_{2}$ for a further $2.5 \mathrm{~h}$. Cells were shocked with $10 \%(\mathrm{v} / \mathrm{v})$ DMSO in growth medium for $2.5 \mathrm{~min}$, which was then replaced with standard growth medium. Transfection using Transfast was performed using $1 \mu \mathrm{g}$ of each DNA and using a charge ratio of lipid reagent to DNA of 1:3. The manufacturer's 

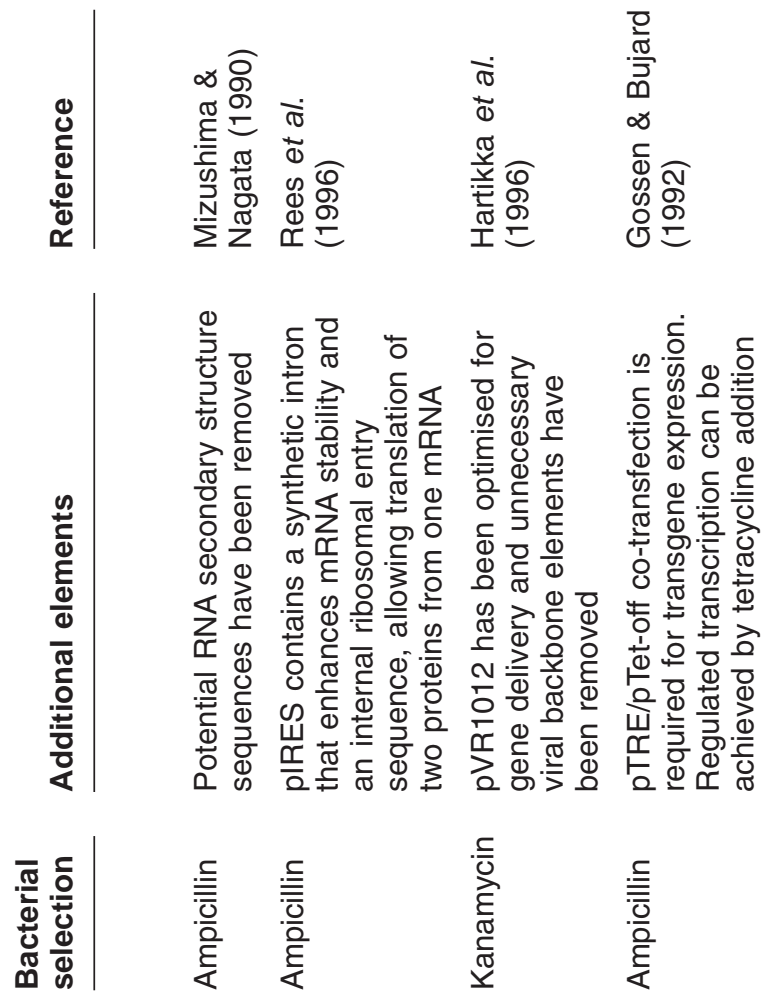

$\frac{\text { 들 }}{\frac{\overline{0}}{2}}$

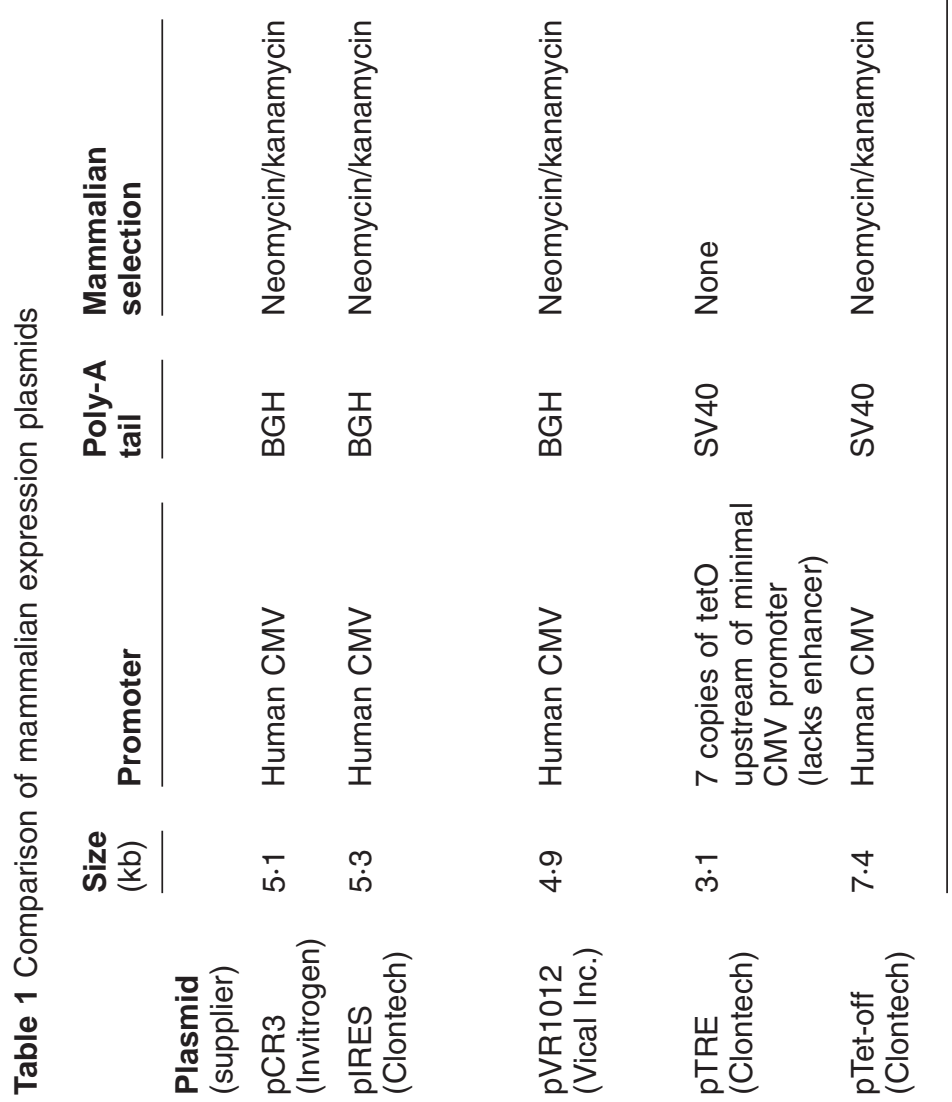


instructions were followed for transfection. Medium was collected and replaced at 24-h intervals and cells were harvested following completion of the experiment.

\section{Tetracycline addition}

Stock tetracycline $(10 \mathrm{mg} / \mathrm{ml}$, Sigma-Aldrich) was made up in $70 \%$ ethanol. Further dilutions were performed in growth medium to give final concentrations ranging from $0.0001 \mu \mathrm{g} / \mathrm{ml}$ to $100 \mu \mathrm{g} / \mathrm{ml}$. After transfection, cells were rested for $24 \mathrm{~h}$ before the addition of tetracycline. Tetracycline supplemented medium was replaced at 24-h intervals.

\section{1 and 1014 pro/insulin radioimmunoassay (RIA)}

Cell medium and extracts (freeze-thawed in PBS) were assayed in duplicate by in-house RIA as described previously (Shaw et al. 2002). Briefly, human recombinant insulin (Sigma-Aldrich) was used as a standard for RIA $(0-5 \mathrm{ng} / \mathrm{ml})$. Nonspecific (1011) and specific (1014) antibodies (Linco Research Inc, St. Charles, MO, USA) were used for the detection of total insulin-like immunoreactivity (ILI) and mature insulin respectively. Tyrosine-14-labelled insulin $\left({ }^{125} \mathrm{I}\right.$, AmershamPharmacia plc), medium/cell extracts and antiinsulin serum were incubated overnight at $4{ }^{\circ} \mathrm{C}$. Precipitating complex ( $\gamma$-globulins and PEG-16000) was added, vortexed, centrifuged and the supernatant discarded. The precipitates were counted for $60 \mathrm{~s}$ using a gamma scintillation counter. All reagents used in the initial incubation mixture were diluted in RIA buffer (50 mM PBS, 25 mM EDTA, $138 \mathrm{mM} \mathrm{NaCl}, 1 \%$ (w/v) BSA, 0.1\% (w/v) $\mathrm{NaN}_{3}$, $\mathrm{pH} \mathrm{7 \cdot 4).}$

\section{Proinsulin and insulin ELISA}

Commercially available human proinsulin and ultrasensitive insulin ELISA kits were purchased from Mercodia, Uppsala, Sweden. Samples were vortexed and centrifuged prior to analysis and the manufacturer's protocol was followed. Completed plates were measured at absorbance $\mathrm{A}_{450}$ on a Dynatech MR 7000 plate reader.

\section{$\beta$-Galactosidase staining}

Cells were fixed in 2\% paraformaldehyde/0.2\% glutaraldehyde in PBS for 5 min at $4{ }^{\circ} \mathrm{C}$. Cells were washed in $\mathrm{PBS}$ and stained in $\mathrm{X}$-gal solution $\left(1.3 \mathrm{mM} \quad \mathrm{MgCl}_{2}, \quad 3 \mathrm{mM} \quad \mathrm{K}_{3} \mathrm{Fe}(\mathrm{CN})_{6}, \quad 3 \mathrm{mM}\right.$ $\mathrm{K}_{4} \mathrm{Fe}(\mathrm{CN})_{6}, 1 \mathrm{mg} / \mathrm{ml} \mathrm{X}$-gal (5-bromo-4-chloro-3indolyl $\beta$-D-galactosidase (Melford Laboratories Ltd, Chelsworth, Suffolk, UK) in PBS) for 2-4 h at $37^{\circ} \mathrm{C}$. To visualise nuclei, Hoechst nuclear stain (Sigma-Aldrich) diluted in PBS $(10 \mathrm{ng} / \mathrm{ml})$ was applied to cells.

\section{Immunocytochemistry}

COS-7 cells were seeded onto coverslips (washed in a solution of $1 \%$ DECON, rinsed thoroughly and autoclaved) in 6-well plates. Cells were fixed using $5 \%(\mathrm{v} / \mathrm{v})$ acetic acid/ethanol for $10 \mathrm{~min}$ at room temperature then at $-20{ }^{\circ} \mathrm{C}$ for $20 \mathrm{~min}$. All further procedures were carried out at room temperature. Non-specific antibody binding was blocked using blocking buffer $(2 \%(\mathrm{w} / \mathrm{v})$ BSA, $0 \cdot 2 \%(\mathrm{v} / \mathrm{v})$ Tween$20,6 \cdot 7 \%(\mathrm{v} / \mathrm{v})$ glycerol in PBS) for $1 \mathrm{~h}$. Primary antibodies: guinea pig anti-human insulin (provided by Prof. A Bone, University of Brighton, UK) and mouse anti-human vimentin (Sigma-Aldrich) were diluted in blocking buffer $(1 / 500$ and 1/50 respectively) and applied to cells for $1 \mathrm{~h}$. Cells were then washed four times in washing buffer $(2 \%(\mathrm{w} / \mathrm{v}) \mathrm{BSA}$, $0 \cdot 4 \%(\mathrm{v} / \mathrm{v})$ Tween-20, 6.7\% (v/v) glycerol in PBS). Secondary antibodies (Sigma-Aldrich): rabbit antimouse TRITC (tetramethylrhodamine isothiocyanate) conjugate and mouse anti-guinea pig FITC (fluorescein isothiocyanate) conjugate were diluted in blocking buffer to $1 / 250$ and added to cells for $1 \mathrm{~h}$ in darkness. After a further four washes in wash buffer, coverslips were mounted in Vectashield aqueous mounting medium containing DAPI $(4,6-$ diamidino-2-phenylindole) nuclear stain (Vector Laboratories Ltd, Peterborough, UK) and analysed by digital fluorescence microscopy. Fluorescence microscopy was carried out using a Zeiss Axioplan II transmission microscope with images captured using a Photometrics Sensys camera and recorded using VijsisQuips software (Vysis, Surrey, UK).

\section{Cell counts}

Trypan Blue $(0 \cdot 4 \%$, Invitrogen Ltd.) exclusion was used to count viable cells on a haemocytometer. 

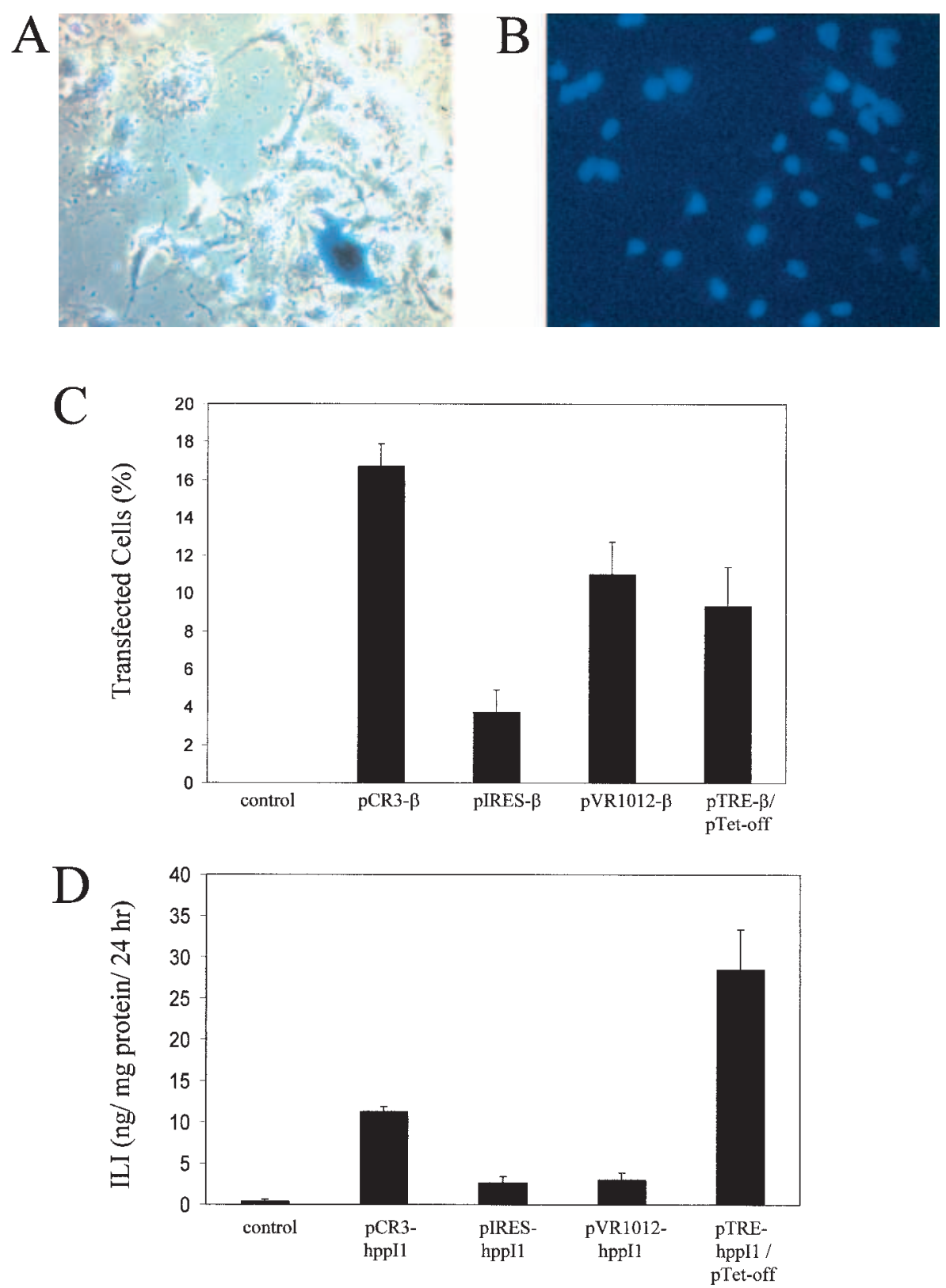

Figure 1 Comparison of vector efficiency in the COS-7 cell line. COS-7 cells were transfected with empty plasmid (control) or plasmids encoding transgenes for $\beta$-galactosidase (pCR3- $\beta$, pIRES- $\beta$, pVR1012- $\beta$ and pTRE- $\beta / p$ Tet-off) and hppl1 (pCR3-hppl1, pIRES-hppl1, pVR1012-hppl1 and pTRE-hppl1/pTet-off). $\beta$-Galactosidase-transfected cells were fixed and stained with (A) X-gal and (B) Hoechst nuclear stain $48 \mathrm{~h}$ post-transfection (magnification $\times 200$ ). (C) The number of X-gal- and nuclear-stained cells in 8 fields of view (4 central and 4 peripheral) were counted for each well and the mean determined (percentage of positively transfected cells $=($ mean X-gal-positive cells per field $/$ mean total number of cells (measured by nuclear staining) per field) $\times 100$ ). The results are from three separate experiments $(n=3$, mean \pm S.D). (D) COS-7 cells were transfected with plasmids encoding hppl1. Following transfection, medium was changed after 24 and $48 \mathrm{~h}$, cells were incubated for a further $24 \mathrm{~h}$, after which the medium was harvested, representing 48-72 h. Intracellular protein concentrations were measured and pro/insulin levels adjusted accordingly. ILI (insulin-like immunoreactivity) was measured by $1011 \mathrm{RIA}$ and is expressed as ng/mg protein/24 h ( $n=3$, mean \pm S.D). 


\section{RNA isolation and Northern blotting}

Preproinsulin mRNA levels were analysed by Northern blotting. Total RNA was isolated from cultured cells in $1 \mathrm{ml}$ TRIZOL reagent (Invitrogen Ltd.) following the manufacturer's instructions. To
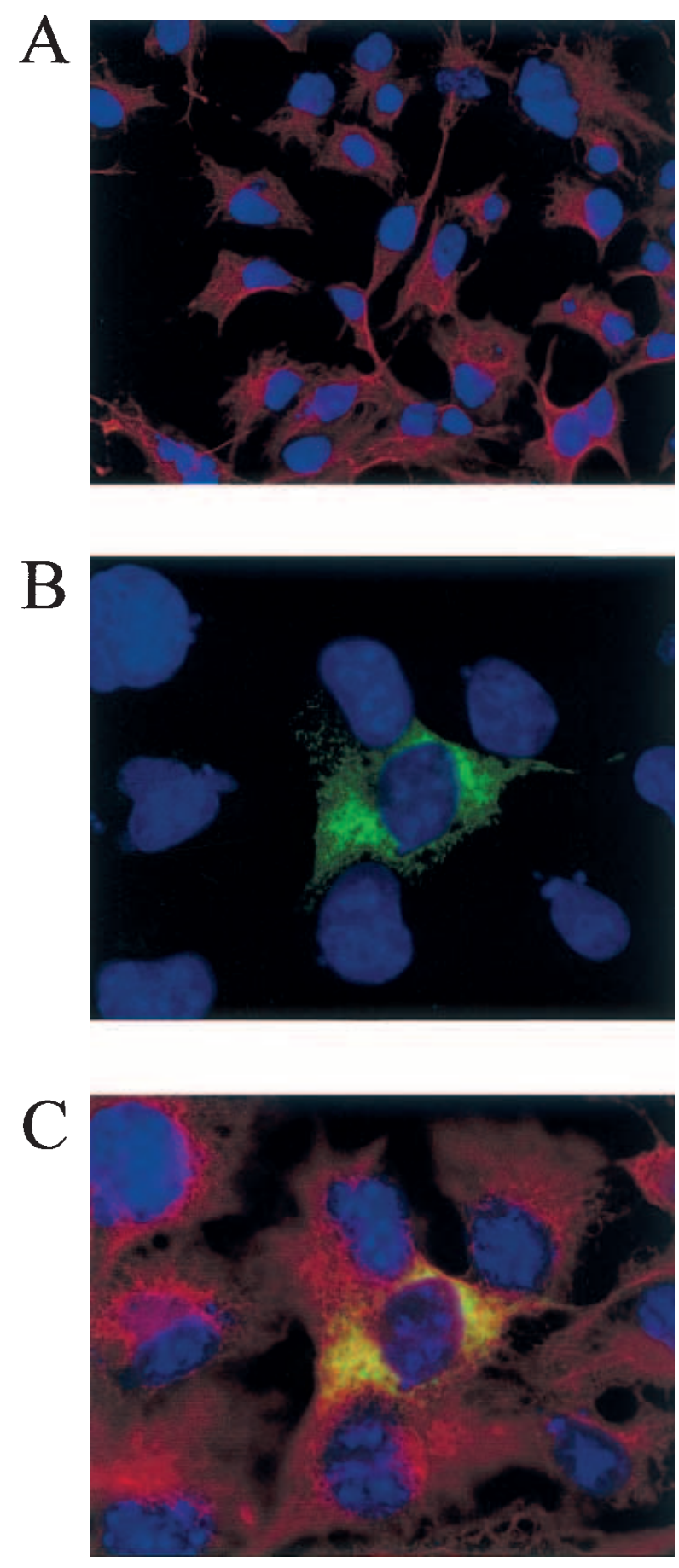

www.endocrinology.org determine equal loading, RNA was loaded onto a $1 \%$ agarose gel and stained with ethidium bromide. Approximately $10 \mu \mathrm{g}$ total RNA were loaded onto a $1 \cdot 2 \%$ agarose gel containing formaldehyde, morpholinopropane-sulphonic acid (MOPS), sodium acetate, EDTA $\mathrm{pH} 7 \cdot 0$ and transferred onto a nitrocellulose $\mathrm{N}^{+}$membrane (Hybond, Amersham-Pharmacia plc.) using the capillary blotting technique. Hybridisation was performed with a digoxigenin (DIG)-labelled antisense RNA encoding the preproinsulin gene. Procedures were carried out according to the manufacturer's guidelines (Roche Diagnostics Ltd, Lewes, East Sussex, UK). Plasmid pCR3-hppIl was linearised (BamHI) and used as a template for in vitro RNA transcription (SP6 RNA polymerase) in the presence of DIG-11-UTP to create the preproinsulin probe.

\section{Statistical analysis}

Values are reported as means \pm standard deviation (S.D.). Data were analysed by one-way analysis of variance (ANOVA) and Student's $t$-test. A $P$ value of $<0.05$ was accepted as statistically significant.

\section{Results}

\section{Transgene expression in transiently transfected COS-7 cells}

GOS-7 cells were transiently transfected with plasmids (pCR3, pIRES, pVR1012 and pTRE/

Figure 2 Immunocytochemical staining of transfected COS-7 cells. Cells were fixed, then incubated with guinea pig anti-insulin (1/500) and mouse anti-vimentin $(1 / 50)$ primary antibodies as described in the methods section. Anti-guinea pig FITC (1/250) conjugate and anti-mouse TRITC conjugate (1/250) secondary antibodies were used to visualise insulin (green) and vimentin (red) staining. Nuclei were stained with DAPI blue. (A) Triple stain of COS-7 cells co-transfected with pTRE (no insert)/pTet-off. Vimentin (red) and nuclear (blue) staining are demonstrated. Insulin staining (green) is absent (magnification $\times 400)$. (B and C) COS-7 cells co-transfected with pTRE-hppl1/pTet-off. Double nuclear and insulin staining demonstrates a single, successfully co-transfected cell ( $B$, magnification $\times 650$ ). Triple staining of the same field confirms vimentin expression in a cell expressing the insulin transgene in addition to DAPI blue nuclear staining (C, magnification $\times 650)$. 
Table 2 Percentage inhibition of pro/insulin secretion by tetracycline. COS-7 cells were co-transfected with either pTRE-hppl1/pTet-off or pTRE-hppl4/pTet-off. Tetracycline was added after $24 \mathrm{~h}$ and again at $48 \mathrm{~h}$ post-transfection to fresh medium at final concentrations of $0.01,0.1$ and $1.0 \mu \mathrm{g} / \mathrm{ml}$. In separate experiments medium was harvested after $24(n=3)$ and $48(n=2)$ h tetracycline incubations (48 and $72 \mathrm{~h}$ post-transfection respectively) and total pro/insulin levels were measured by $1011 \mathrm{RIA}$. Pro/insulin levels from tetracycline-treated cells are expressed as a percentage over untreated cells (100\%)

\begin{tabular}{|c|c|c|c|c|}
\hline & pTRE- & t-off & pTRE- & t-off \\
\hline & $24 \mathrm{~h}$ & $48 \mathrm{~h}$ & $24 \mathrm{~h}$ & $48 \mathrm{~h}$ \\
\hline $\begin{array}{l}\text { Tetrac } \\
\text { conce } \\
(\mu \mathrm{gl} / \mathrm{l}\end{array}$ & & & & \\
\hline 0.000 & $100 \%$ & $100 \%$ & $100 \%$ & $100 \%$ \\
\hline 0.01 & $66 \%$ & $50 \%$ & $65 \%$ & $29 \%$ \\
\hline 0.1 & $38 \%$ & $7 \%$ & $36 \%$ & $5 \%$ \\
\hline 1.0 & $40 \%$ & $9 \%$ & $46 \%$ & $6 \%$ \\
\hline
\end{tabular}

pTet-off) encoding transgenes for $\beta$-galactosidase $(\beta)$ and wild-type human preproinsulin (hppI1). Transfection efficiency was determined by two methods. First, by determination of percentage transfection efficiency by microscopic quantification, whereby the number of blue, $\mathrm{X}$-gal stained cells (Fig. 1A) and the total number of cells visualised by Hoechst nuclear stain (Fig. 1B) were counted. Transfected cells were expressed as a percentage over the total cell count in a field of view (Fig. 1C). Secondly, the total amount of pro/insulin secreted from transfected cells was measured using RIA (Fig. 1D).

There was no background $\mathrm{X}$-gal staining visualised in cells transfected with plasmids containing no transgene inserts. The highest percentage of X-gal-positive cells was seen following transfection with pCR3- $\beta(16 \cdot 7 \%)$, followed by pVR1012- $\beta$ (11.0\%), pTRE- $\beta$ /pTet-off (9.3\%) and pIRES- $\beta(3 \cdot 7 \%)$. In contrast, co-transfection with pTRE-hppIl and pTet-off resulted in maximal secretion of total pro/insulin into the surrounding culture medium $(28.48 \mathrm{ng} / \mathrm{mg}$ protein $/ 24 \mathrm{~h}) \mathrm{com}$ pared with pCR3-hppIl (11.28 ng/mg protein/ $24 \mathrm{~h}), \mathrm{pVR} 1012-\mathrm{hppI} 1$ (3.03 ng/mg protein/24 h) and pIRES-hppIl (2.68 ng/mg protein/24 h). Secreted pro/insulin levels were adjusted for intracellular protein concentration.

If the levels of secreted pro/insulin are divided by the percentage of $\beta$-galactosidase-positive cells, a comparison of relative promoter strength, mRNA stability and efficiency of translation for each plasmid can be made. Co-transfection of pTRE and pTet-off $(3.06 \mathrm{ng} / \mu \mathrm{g}$ protein $/ 24 \mathrm{~h} /$ percent of transgene expressing cells) resulted in an 11-fold higher amount of pro/insulin secreted by each cell expressing both transgenes in comparison with pVR1012 transfection $(0 \cdot 28)$. By this method, expression was 4.25 times greater in cells transfected with pTRE/pTet-off in comparison with pIRES $(0.72)$ and 4.5 times greater than with pCR3 $(0 \cdot 68)$. These results indicate that even if basic promoter/poly A structures are similar, apparently minor variations can lead to considerable differences in transgene expression by cells which have taken up and retained the plasmid.

\section{Immunocytochemical confirmation of insulin biosynthesis and vimentin expression in transiently transfected COS-7 cells}

Pro/insulin biosynthesis following pTRE-hppIl/ pTet-off co-transfection, together with expression of the mesenchymal marker vimentin in COS7 cells was confirmed by immunocytochemical staining (Fig. 2).

\section{Regulation of pro/insulin secretion by tetracycline in transiently transfected COS-7 cells}

The potential for regulated pro/insulin secretion by tetracycline administration was evaluated in COS7 cells transiently transfected in vitro. Pro/insulin 
secretion detected by 1011 RIA following transfection with pTRE-hppIl and pTRE-hppI4 was not significantly higher than background (pTet-off). In the absence of tetracycline, total pro/insulin secretion was $2.33 \mathrm{ng} / 10^{6}$ cells $/ 24 \mathrm{~h}$ following co-transfection with pTRE-hppIl and pTet-off (Fig. 3A). Addition of $0 \cdot 01,0 \cdot 1$ and $1 \cdot 0 \mu \mathrm{g} / \mathrm{ml}$ tetracycline to medium for $24 \mathrm{~h}(24-48 \mathrm{~h}$ post transfection) reduced the levels of total pro/insulin secreted into the medium to 66,38 and $40 \%$ of untreated cells $(100 \%)$ respectively (Table 2). A similar pattern was observed in pTREhppI4/pTet-off-transfected cells. Total pro/insulin secretion (determined by 1011 RIA) of $0.39 \mathrm{ng} / 10^{6}$ cells $/ 24 \mathrm{~h}$ was attained after co-transfection in the absence of tetracycline (Fig. 3B). Secreted levels were reduced by the addition of $0.01,0 \cdot 1$ and $1.0 \mu \mathrm{g} / \mathrm{ml}$ tetracycline to 65,36 and $46 \%$ of control $(100 \%)$ respectively (Table 2$)$.

In a separate study, medium was harvested after a further 24-h incubation with tetracycline (Table 2). This resulted in a further percentage reduction in pro/insulin secretion to a minimum of $7 \%$ following pTRE-hppIl/pTet-off co-transfection and 5\% after pTRE-hppI4/pTet-off transfection in the presence of $0 \cdot 1 \mu \mathrm{g} / \mathrm{ml}$ tetracycline.

Processing of proinsulin to insulin was assessed in hppIl and hppI4 transfected cells. Levels of secreted mature insulin (determined by 1014 RIA) were compared with total pro/insulin secretion (determined by 1011 RIA). In hppI1-transfected cells, processing of proinsulin to insulin varied from $8-25 \%$ (Fig. 3A). In hppI4-transfected cells, $72-100 \%$ of total ILI was processed to mature insulin (Fig. 3B).

To determine if tetracycline was preventing pro/insulin secretion, intracellular concentrations were measured; they were $2-4 \%$ and $10-16 \%$ of the total amount secreted for pTRE-hppI/pTetoff- and pTRE-hppI4/pTet-off-transfected cells respectively. There was no observed intracellular accumulation of pro/insulin related to increasing tetracycline concentration in co-transfections with pTRE-hppI1/pTet-off or pTRE-hppI4/pTetoff (absence of tetracycline-mediated intracellular accumulation confirmed by ANOVA).

Viable cell numbers were also compared to determine if reduced pro/insulin secretion was due to tetracycline-induced cell death. There were no significant differences observed with increasing concentrations of tetracycline up to $1 \mu \mathrm{g} / \mathrm{ml}$ in either wild-type or mutant co-transfections. Numbers of viable cells per well at $48 \mathrm{~h}$ following in vitro transfection and after exposure to tetracycline for $24 \mathrm{~h}$ were in the range $1 \cdot 2$ $1.4 \times 10^{6}$ following pTRE-hppIl/pTet-off transfection and 2.0-2.6 $\times 10^{6}$ after pTRE-hppI4/pTet transfection.

To determine potential interference of tetracycline with 1011 and 1014 RIAs, tetracycline was added to pCR3-hppIl (a tetracycline unresponsive plasmid)-transfected cells at final concentrations of $0,0 \cdot 01,0 \cdot 1,1,10$ and $100 \mu \mathrm{g} / \mathrm{ml}, 24 \mathrm{~h}$ post-transfection. Medium was harvested a further $24 \mathrm{~h}$ later and assayed by non-specific (1011) and specific (1014) RIA with pro/insulin expressed as $\mathrm{ng} / 10^{6}$ viable cells $/ 24 \mathrm{~h}$. At tetracycline concentrations of $0-10 \mu \mathrm{g} / \mathrm{ml}$ there were no significant differences between treated and untreated groups with either 1011 or 1014 . Only at a tetracycline concentration of $100 \mu \mathrm{g} / \mathrm{ml}$, higher than that used in any of the other studies reported here, were levels of secreted pro/insulin and insulin significantly lower, relating to lower cell numbers at this concentration (data not shown).

\section{Regulation of preproinsulin mRNA expression by tetracycline in transiently transfected COS-7 cells}

To confirm the effect of tetracycline on gene transcription, preproinsulin mRNA levels were analysed by Northern blot. COS-7 cells were transfected individually with plasmids pTet-off, pTRE-hppI 1 and pTRE-hppI4 or co-transfected with pTRE-hppI1/pTet-off and pTRE-hppI4/ pTet-off. Transfected cells were incubated for $24 \mathrm{~h}$, after which tetracycline was added in increasing amounts to give final concentrations of $0 \cdot 01,0 \cdot 1$ and $1.0 \mu \mathrm{g} / \mathrm{ml}$. Cells were incubated for a further two 24-h periods in medium containing tetracycline, then medium was harvested (48-72 h) and total RNA extracted from the cell pellet. Total secreted pro/insulin concentrations were measured by 1011 RIA (Fig. 4A). Samples containing $10 \mu \mathrm{g}$ total RNA were run on a formaldehyde/ $1 \cdot 2 \%$ agarose gel. RNA was also run on a $1 \%$ agarose gel and stained with ethidium bromide to confirm equal loading (Fig. 4B). After separation, the Northern blot was probed with a digoxigeninlabelled preproinsulin antisense RNA (Fig. 4G). 

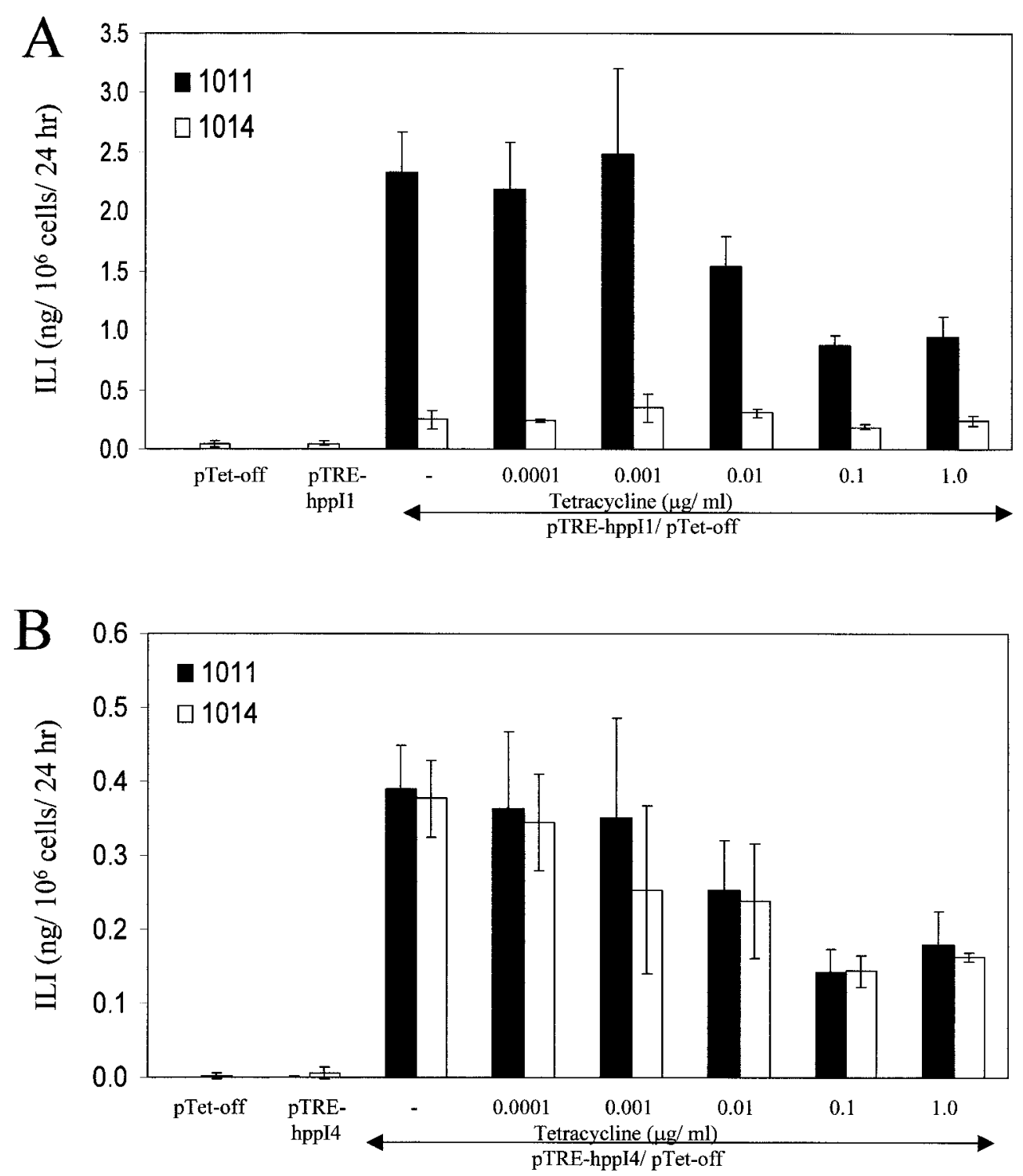

Figure 3 Tetracycline-regulated pro/insulin secretion in COS-7 cells. Cells were transfected with pTRE-hppl1 (A) or pTRE-hppl4 (B) alone and in conjunction with pTet-off. Tetracycline was added to fresh medium at final concentrations ranging from $0-1.0 \mu \mathrm{g} / \mathrm{ml}, 24 \mathrm{~h}$ after transfection. The medium was harvested $24 \mathrm{~h}$ later $(24-48 \mathrm{~h}$ ) and assayed by 1011 (solid bars) and 1014 (open bars) RIA. Cells were trypsinised and cell counts were taken for each well. ILI is expressed as $\mathrm{ng} / 10^{6}$ cells $/ 24 \mathrm{~h}(n=3$, mean \pm S.D $)$.

Proinsulin mRNA was detected only in cotransfection of cells with pTRE-hppIl/pTet-off and pTRE-hppI4/pTet-off in the absence and presence of $0.01 \mu \mathrm{g} / \mathrm{ml}$ tetracycline. In the presence of $0 \cdot 1$ and $1 \cdot 0 \mu \mathrm{g} / \mathrm{ml}$ tetracycline proinsulin mRNA expression was not detected in wild-type or mutant transfections.

\section{Reversal of tetracycline inhibition in transiently transfected COS-7 cells}

To assess reversal of tetracycline inhibition, tetracycline was added to and then removed from transfected cells. Medium was collected every $24 \mathrm{~h}$ and analysed for secreted proinsulin and insulin by 


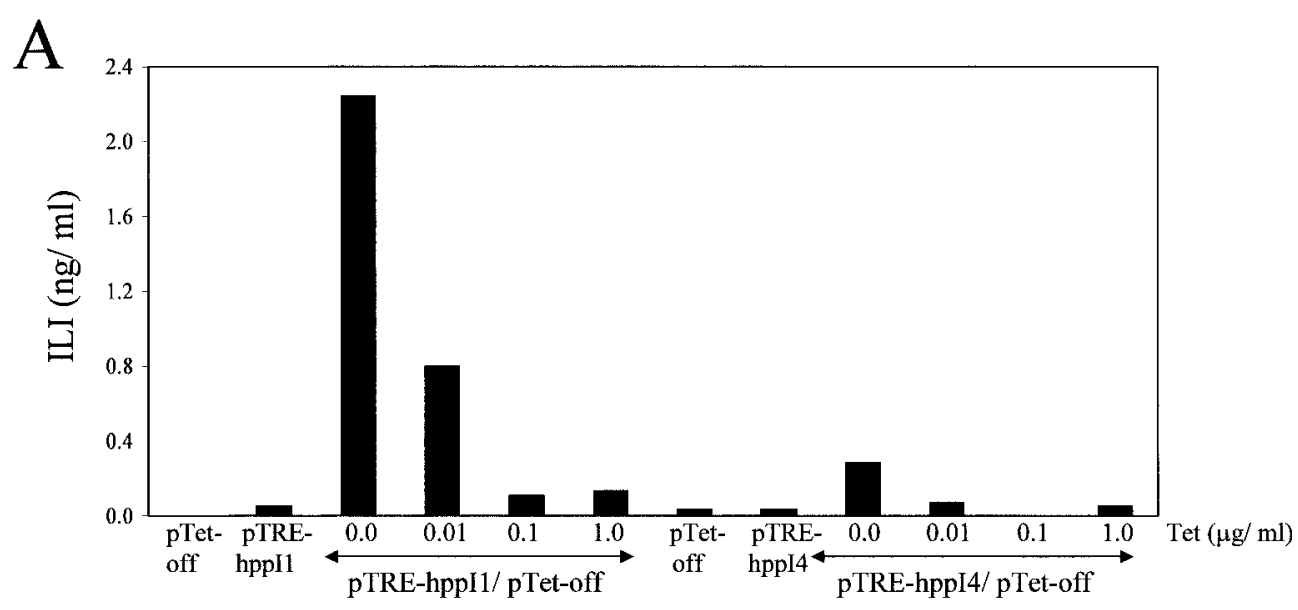

B
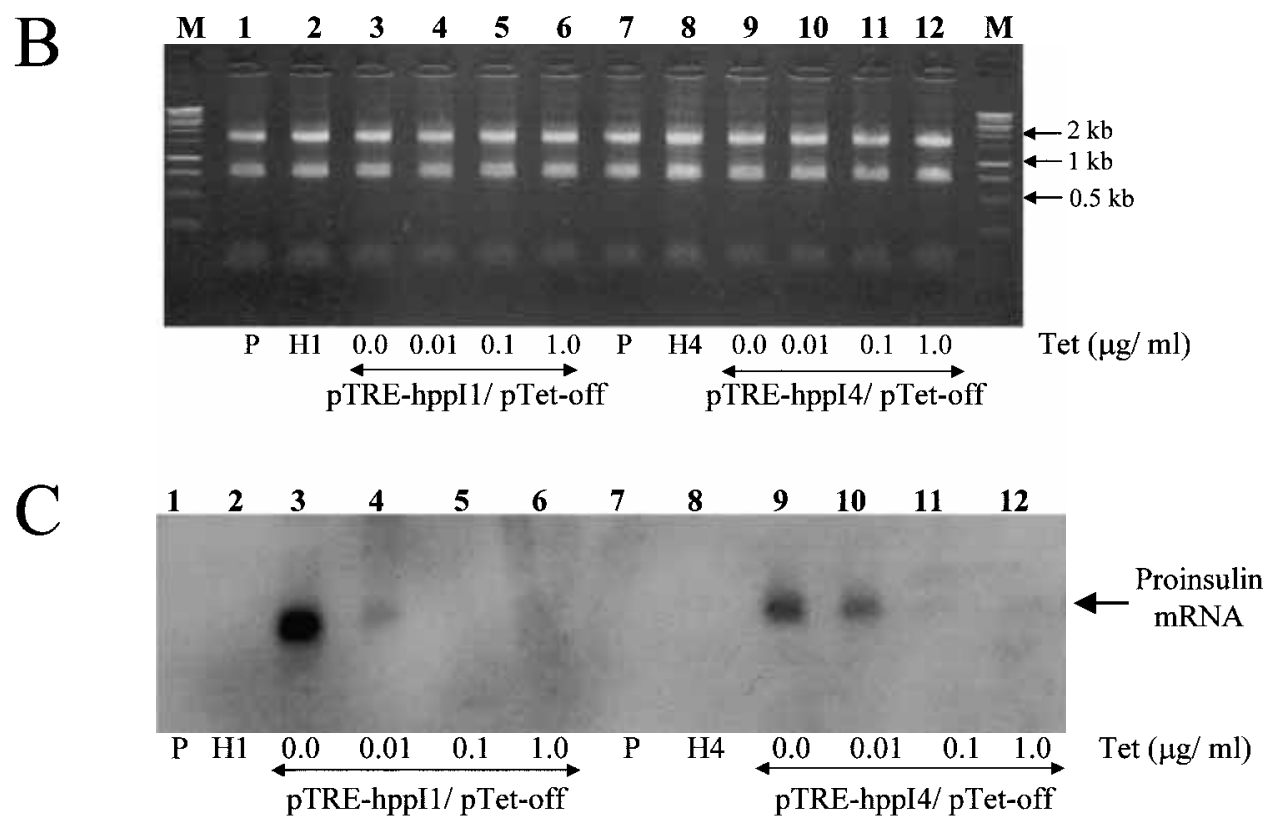

Figure 4 Tetracycline-regulated preproinsulin transcription in COS-7 cells. COS-7 cells were transfected with pTRE-hppl1 $(\mathrm{H} 1)$ or pTRE-hppl4 $(\mathrm{H} 4)$ alone and in conjunction with pTet-off $(P)$. Tetracycline was added to fresh medium at final concentrations of $0.01,0.1$ and $1.0 \mu \mathrm{g} / \mathrm{ml}, 24$ and $48 \mathrm{~h}$ after transfection. (A) The medium was harvested $48 \mathrm{~h}$ after initial tetracycline addition (48-72 h), assayed by $1011 \mathrm{RIA}$ and ILI is expressed as $\mathrm{ng} / \mathrm{ml}$. Cells were lysed in TRIZOL. (B) Total RNA was extracted and analysed by $1 \%$ agarose gel electrophoresis to confirm equal loading. (C) Total RNA $(10 \mu \mathrm{g})$ was analysed by Northern blot and probed with an antisense preproinsulin DIG-labelled RNA.

ELISA. COS-7 cells were transfected with pTREhppI/pTet-off and pTRE-hppI4/pTet-off using Transfast. Transfast was used to improve transgene expression from transient transfections. Transfected wells were separated, 1 day after transfection, into three groups: (1) tetracycline untreated, (2) $48 \mathrm{~h}$ tetracycline $(1 \cdot 0 \mu \mathrm{g} / \mathrm{ml})$ treated, with subsequent removal or (3) continually treated with tetracycline $(1.0 \mu \mathrm{g} / \mathrm{ml})$. In the absence of tetracycline (group 1), total pro/insulin secretion peaked at day 3 for both hppIl (1623 pmol/l) and hppI4 (65 pmol/l) transfections. For comparison, tetracycline-treated 
groups are expressed as a percentage over untreated (Fig. 5A and B). Continuous addition of $1 \mu \mathrm{g} / \mathrm{ml}$ tetracycline (group 3) to pTRE-hppIl/ pTet-off-transfected cells reduced the total pro/ insulin secreted with respect to untreated cells by 43,10 and $7 \%$ over days 2,3 and 4 respectively, after which a level of $7 \%$ was maintained. For pTRE-hppI4/pTet-off-transfected cells, addition of tetracycline continuously (group 3) reduced the total pro/insulin secreted by 40,14 and $12 \%$ over days 2, 3 and 4 respectively, after which a level of 6-12\% was maintained. In group 2, tetracycline was added for 2 days before being removed. During incubation with tetracycline secreted pro/insulin levels were similar to the tetracycline continually treated group. Upon removal of tetracycline, proinsulin secretion increased to 13, 55 and 92\% for pTRE-hppI/pTet-off-transfected cells and 26, 61 and 95\% for pTRE-hppI4/pTetoff-transfected cells over days 4,5 and 6 respectively compared with untreated groups. At the end of the study intracellular protein concentrations were quantified. Although there was a marginal decrease in protein levels in tetracyclinetreated $(0.81-0.93 \mathrm{mg} / \mathrm{ml})$ compared with untreated $(1 \cdot 0-1 \cdot 1 \mathrm{mg} / \mathrm{ml})$ groups this was not significant $(P=0 \cdot 819$, ANOVA).

\section{Discussion}

In these studies, efficiency of transgene expression following transient transfection of the COS-7 fibroblast cell line, with a range of plasmids under the control of a constitutive GMV or a tetracycline repressible promoter has been compared employing a $\beta$-galactosidase reporter gene and a wild-type human preproinsulin gene. Highest pro/insulin secretion was attained on co-transfection with a tetracycline repressible transactivator plasmid and a construct in which preproinsulin was expressed under the control of a tetracycline responsive element. Regulation of pro/insulin secretion, mediated by changes in transgene transcription, by addition of tetracycline, was confirmed employing the tetracycline regulatable wild-type preproinsulin plasmid and an equivalent construct engineered to facilitate post-translational processing by furin. Moreover, in mutant transfections, greater than $70 \%$ of total pro/insulin secreted was fully processed to mature insulin.
The highest percentage of cells expressing the $\beta$-galactosidase transgene was achieved with the pCR3- $\beta$ plasmid in COS-7 cells. X-gal staining of $\beta$-galactosidase-expressing cells was very clear allowing identification of positively transfected cells without ambiguity. It would be envisaged that, employing a single transfection method, the percentage of cells taking up each of the plasmids would be comparable. Efficiency of nuclear localisation of plasmid DNA following uptake is dependent on cell type and appears to be influenced by degree of degradation within the cytosol by nucleases (Coonrod et al. 1997, Pollard et al. 2001). We have previously reported enhanced preproinsulin transgene expression in primary fibroblasts in the presence of lysosomal nuclease inhibitors (Shaw et al. 2002). It may be that the plasmids employed in the present studies differed in their susceptibility to nuclease degradation.

Pro/insulin transgene expression was used to compare efficiencies of different plasmids, cotransfection with pTRE-hppIl and pTet-off being most effective. An estimation of relative promoter strength, mRNA stability and translational efficiency was calculated by dividing the levels of pro/insulin secreted into the medium by the percentage of cells expressing the $\beta$-galactosidase reporter gene. Using this method, efficiency of transgene expression by positive transfected cells was higher with pTRE/pTet-off followed by pIRES, pCR3 and pVR1012. The plasmids pVR1012, pCR3 and pIRES all contain the GMV promoters and BGH termination sequences. The presence of a synthetic intron, reported to increase the stability of mRNA in pIRES and modification of pCR3 to remove potential RNA secondary structure sequences may account for higher relative transgene expression compared with pVR1012.

Tetracycline-responsive transcriptional regulation of preproinsulin transgene expression was evaluated to determine the feasibility of controlling therapeutic protein secretion in a transfected non-endocrine cell line. Pro/insulin secretion was reduced in a dose-dependent manner on 24-h incubation with tetracycline, with further reduction to less than $14 \%$ after a 48 -h incubation; this was sustained over a period of 4 days. Reversibility of tetracycline repression was demonstrated, requiring 3 days of incubation without tetracycline before pro/insulin secretion levels were similar to untreated cells. Although preproinsulin mRNA was 


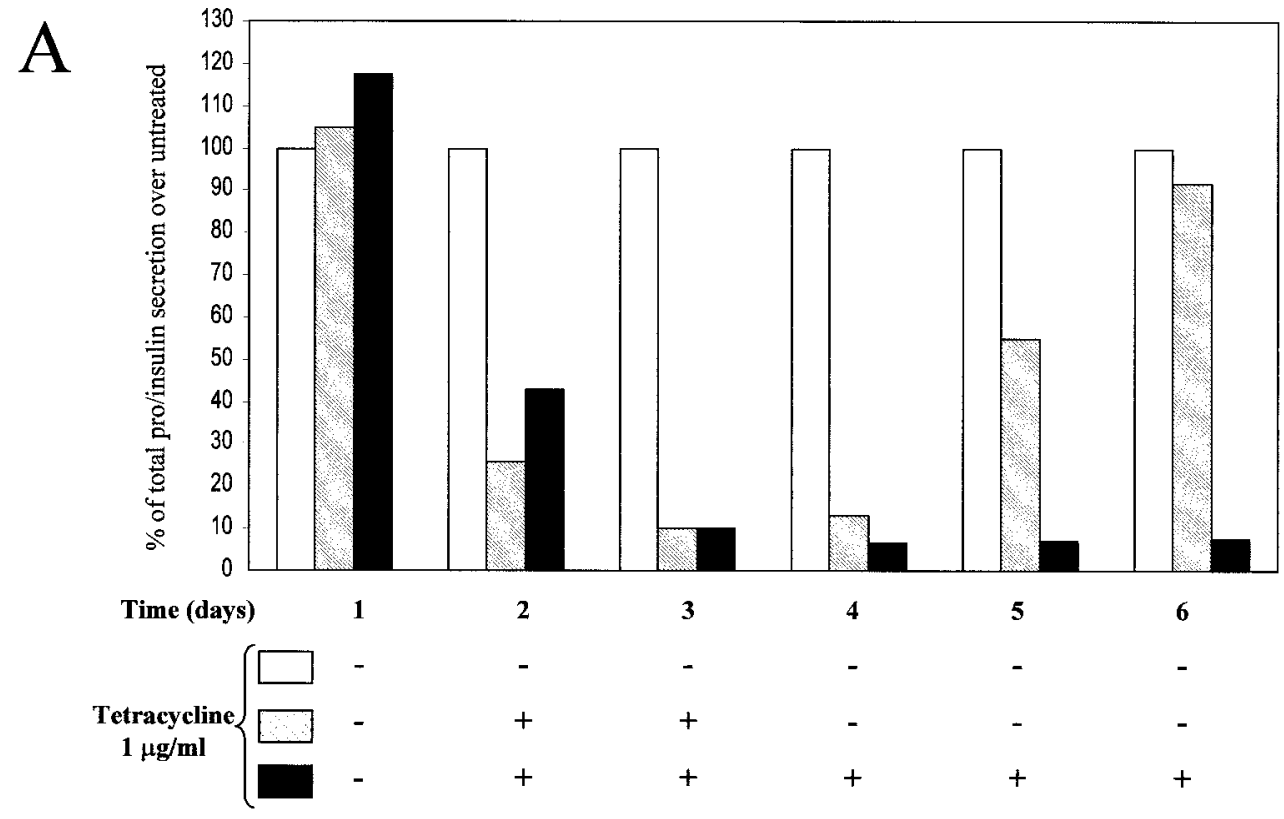

B

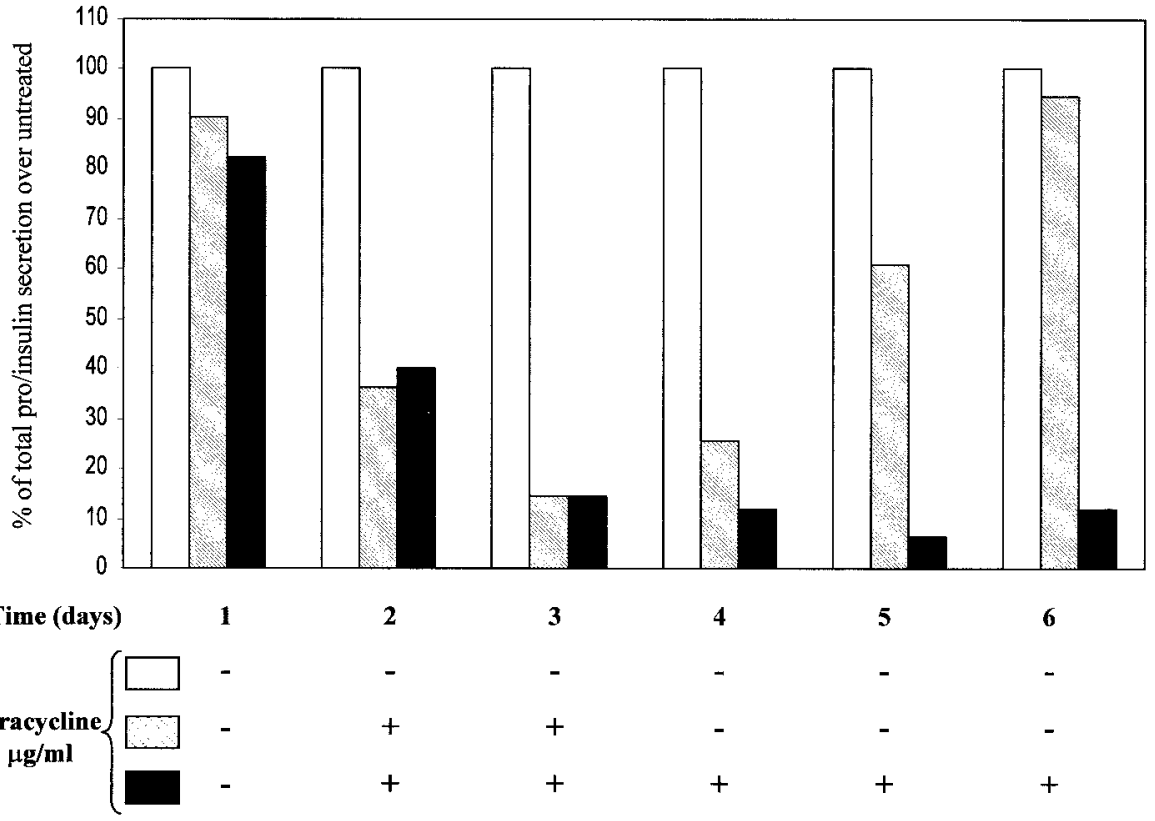

Figure 5 Reversal of tetracycline inhibition of pro/insulin secretion in transfected COS-7 cells. COS-7 cells were transfected with pTRE-hppl1/pTet-off (A) or pTRE-hppl4/pTet-off (B). Tetracycline was omitted (open bars), added during days 2 and 3 only (hatched bars) or added continuously after day 1 (solid bars) to culture medium post-transfection.

Tetracycline was added at a final concentration of $1.0 \mu \mathrm{g} / \mathrm{ml}$. The medium was harvested every $24 \mathrm{~h}$ and assayed using ELISAs. The total pro/insulin levels (proinsulin and insulin) are expressed as a percentage over the tetracycline-untreated group. 
undetectable after 48-h exposure to a tetracycline concentration of $0 \cdot 1 \mu \mathrm{g} / \mathrm{ml}$ or above, secreted pro/insulin remained measurable at $0.1 \mu \mathrm{g} / \mathrm{ml}$ tetracycline and could not be reduced by increasing the concentration to $1.0 \mu \mathrm{g} / \mathrm{ml}$. This finding is in contrast to another study, where there was no detectable transgenic protein secretion at $0 \cdot 1 \mu \mathrm{g} / \mathrm{ml}$ tetracycline (Sturtz et al. 1998). Tetracycline derivatives such as doxycycline demonstrate increased affinity for the transactivator and may enable complete inhibition of pro/insulin secretion at comparable concentrations. This transcriptional system has also been refined as a single plasmid containing both tetracycline repressible transactivator and tetracycline responsive element (O'Brien et al. 1997), and for the expression of two genes in a mutually exclusive manner (Baron et al. 1999).

Transient transfection of the COS-7 cell line with the mutant insulin construct (hppI4) resulted in approximately $80 \%$ lower levels of total pro/insulin secretion in comparison with equivalent wild-type (hppIl) transfections. Levels of rat proinsulin secretion were $40-50 \%$ lower in COS-7, CHO, HepG2 and HIH3T3 cells transfected with a mutant plasmid engineered to facilitate furin cleavage compared with wild-type transfections (Yanagita et al. 1993). This appears to be a consistent finding in all reported studies of unmodified and modified insulin gene transfer to non-endocrine cells, although the underlying mechanism remains unclear. Rapid internalisation and metabolism of insulin following binding to the insulin receptor or increased proteolytic degradation within the medium in comparison with unprocessed proinsulin may provide at least a partial explanation (Vollenweider et al. 1992).

Greater than $70 \%$ of total pro/insulin secreted by COS-7 cells transfected with the mutant insulin construct represented mature unmodified human insulin. In previous COS-7 cell studies employing rat insulin constructs, $<5 \%$ processing was reported with wild-type and $60 \%$ with mutant transfections (Yanagita et al. 1993). Processing of both wild-type and mutant propeptides may be limited by endogenous furin expression. Correlation between furin level and processing in a range of nonendocrine cell types has been described in addition to enhanced processing in both wild-type and mutant transfections on furin co-transfection (Yanagita et al. 1993, Shaw et al. 2002).
The application of this system as a sole treatment for diabetes mellitus would be limited for four main reasons. First, physiological insulin secretion is linked to glucose levels and there is no mechanism for glucose sensing within this system. Secondly, insulin is secreted in two phases, the first acute phase lasting minutes followed by a sustained secondary phase. The system described here requires days to efficiently switch off and switch on insulin secretion, so could not be used for a rapid first phase response. Thirdly, the system is regulated at the level of transcription and not at exocytosis; therefore if a quicker acting derivative were used there would still be a time delay of hours (to allow for transcription, translation, protein synthesis and processing) between antibiotic addition and insulin secretion. Fourthly, the cells used (COS-7) do not have the capacity to store peptides and, therefore, if tetracycline regulation were linked to exocytosis there would not be a sufficient build-up of insulin for an abundant release upon stimulation.

The requirements mentioned above are necessary for an efficient first phase insulin response. Near physiological, post-prandial first phase insulin profiles can now be effectively replicated by injection of a short-acting insulin analogue at meal times. This, however, has highlighted the need for restoration of basal insulin secretion, which is maintained at a constant low level between meals and through the night in those without diabetes (Bolli et al. 1999). Tetracycline-mediated transcriptional regulation of insulin secretion by transfected non-endocrine cells offers the potential of longterm restoration of basal insulin secretion, together with a mechanism for titrating circulating background insulin levels according to fasting and late post-prandial glucose. A further advantage is that tetracycline could be used to 'switch off' insulin expression in the event of dangerous hypoglycaemia. Despite the advent of novel long-acting insulin analogues, none of the available insulin formulations for subcutaneous injection have been able to mimic physiological basal insulin replacement leading to a continued risk of hypoglycaemia due to inappropriate peaks and troughs of insulin action over a 24-h period (Owens et al. 2001).

A further benefit of this system is the concomitant secretion of C-peptide with insulin. C-peptide was originally thought to have no biological function except to participate in insulin 
synthesis; however recent studies have indicated that it has a biological role with important physiological effects. C-peptide has been demonstrated to improve renal function, nerve function and glucose utilisation in animal and human studies of diabetes mellitus (Wahren et al. 2000). C-peptide elicits its effects by binding to cell membrane via $\mathrm{G}$ protein-coupled receptors (Rigler et al. 1999). In this study, the wild-type proinsulin cDNA has been altered so that the 31-amino acid C-peptide has been mutated by two amino acids at both termini to produce basic residues to promote furin cleavage. Mutation into the C-peptide to allow processing by furin may alter receptor binding of C-peptide. A recent paper, however, demonstrated that $\mathrm{Glu}^{27}$ was crucial for binding and is unaltered in our mutant (Pramanik et al. 2001). However, further studies would be necessary to demonstrate effective C-peptide membrane binding.

In conclusion, these studies provide important proof of principle for the use of non-endocrine cells to restore basal secretion of fully processed unmodified human insulin that can be safely titrated and 'turned down' to prevent hypoglycaemia. Efficient transgene expression has been demonstrated in vitro despite the use of a two-plasmid system without viral vectors or selection of stably transfected clones. Potential future therapeutic applications with this approach include intramuscular reimplantation of ex vivo transfected host-derived dermal fibroblasts or myoblasts with subsequent uptake into muscle fibres mediating sustained background insulin secretion. Moreover, successful delivery of these plasmids to host muscle offers the potential of long-term gene therapy mediated by simple intramuscular injection avoiding the need for cell culture, transplantation, immunosuppression or toxic small molecule transcriptional regulators. Although physiological minute-to-minute insulin secretion would not be attainable, this approach may be sufficient as a basal insulin treatment for individuals with Type 2 diabetes and may help those with Type 1 diabetes who are not complying with daily insulin injections. Truly constant basal insulin levels may facilitate more physiological glycaemic control with reduced hypoglycaemia in combination with preprandial injections of fastacting insulin. Refinement of this technique also holds promise for the treatment of a broader range of endocrine and other disorders.

\section{Acknowledgements}

Dr K T Scougall was supported by a grant from the Scottish Hospitals Endowments Research Trust (SHERT). Dr J A M Shaw was supported by a Glaxo Wellcome Senior Clinical Fellowship. We wish to thank Prof. K Docherty for provision of hppI 1 and hppI4 cDNAs and Vical Inc. for making the pVR1012 plasmid freely available to us.

\section{References}

Abai AM, Hobart PM \& Barnhart KM 1999 Insulin delivery with plasmid DNA. Human Gene Therapy 10 2637-2649.

Baron U, Schnappinger D, Helbl V, Gossen M, Hillen W \& Bujard H 1999 Generation of conditional mutants in higher eukaryotes by switching between the expression of two genes. PNAS 96 1013-1018.

Blau HM \& Rossi FM 1999 Tet B or not tet B: advances in tetracycline-inducible gene expression. PNAS 96 797-799.

Bolli GB, Di Marchi RD, Park GD, Pramming S \& Koivisto VA 1999 Insulin analogues and their potential in the management of diabetes mellitus. Diabetologia 42 1151-1167.

Bou-Gharios G, Wells DJ, Lu QL, Morgan JE \& Partridge T 1999 Differential expression and secretion of alpha 1 anti-trypsin between direct DNA injection and implantation of transfected myoblast. Gene Therapy 6 1021-1029.

Brower V 1998 Naked DNA vaccines come of age. Nature Biotechnology 16 1304-1305.

Coonrod A, Li FQ \& Horwitz M 1997 On the mechanism of DNA transfection: efficient gene transfer without viruses. Gene Therapy 4 1313-1321.

van Deutekom JC, Floyd SS, Booth DK, Oligino T, Krisky D, Marconi P, Glorioso JC \& Huard J 1998 Implications of maturation for viral gene delivery to skeletal muscle. Neuromuscular Disorders 8 135-148.

Dhawan J, Pan LC, Pavlath GK, Travis MA, Lanctot AM \& Blau HM 1991 Systemic delivery of human growth hormone by injection of genetically engineered myoblasts. Science $\mathbf{2 5 4}$ 1509-1512.

Dhawan J, Rando TA, Elson SL, Bujard H \& Blau HM 1995 Tetracycline-regulated gene expression following direct gene transfer into mouse skeletal muscle. Somatic Cell Molecular Genetics $21233-240$.

Falqui L, Martinenghi S, Severini GM, Corbella P, Taglietti MV, Arcelloni C, Sarugeri E, Monti LD, Paroni R, Dozio N, Pozza G \& Bordignon C 1999 Reversal of diabetes in mice by implantation of human fibroblasts genetically engineered to release mature human insulin. Human Gene Therapy 10 1753-1762.

Gossen M \& Bujard H 1992 Tight control of gene expression in mammalian cells by tetracycline-responsive promoters. PNAS $\mathbf{8 9}$ $5547-5551$.

Hartikka J, Sawdey M, Cornefert-Jensen F, Margalith M, Barnhart K, Nolasco M, Vahlsing HL, Meek J, Marquet M, Hobart P, Norman J \& Manthorpe M 1996 An improved plasmid DNA expression vector for direct injection into skeletal muscle. Human Gene Therapy 7 1205-1217.

Heartlein MW, Roman VA, Jiang JL, Sellers JW, Zuliani AM, Treco DA \& Selden RF 1994 Long-term production and delivery of human growth hormone in vivo. PNAS 91 10967-10971.

High KA 2001 AAV-mediated gene transfer for hemophilia. Annals of the New York Academy of Sciences $\mathbf{9 5 3}$ 64-74. 
Hortelano G, Wang L, Xu N \& Ofosu FA 2001 Sustained and therapeutic delivery of factor IX in nude haemophilia B mice by encapsulated C2C12 myoblasts: concurrent tumorigenesis. Haemophilia 7 207-214.

Kawakami Y, Yamaoka T, Hirochika R, Yamashita K, Itakura M \& Nakauchi H 1992 Somatic gene therapy for diabetes with an immunological safety system for complete removal of transplanted cells. Diabetes 41 956-961.

Kon OL, Sivakumar S, Teoh KL, Lok SH \& Long YC 1999 Naked plasmid-mediated gene transfer to skeletal muscle ameliorates diabetes mellitus. Fournal of Gene Medicine 1 186-194.

Liu F \& Huang L 2002 Development of non-viral vectors for systemic gene delivery. Fournal of Controlled Release 78 259-266.

Lopata MA, Cleveland DW \& Sollner-Webb B 1984 High level transient expression of a chloramphenicol acetyl transferase gene by DEAE-dextran mediated DNA transfection coupled with a dimethyl sulfoxide or glycerol shock treatment. Nucleic Acids Research 12 5707-5717.

Luthman H \& Magnusson G 1983 High efficiency polyoma DNA transfection of chloroquine treated cells. Nucleic Acids Research 11 1295-1308.

MacColl GS, Goldspink G \& Bouloux PM 1999 Using skeletal muscle as an artificial endocrine tissue. Fournal of Endocrinology 162 $1-9$.

Mizushima S \& Nagata S 1990 pEF-BOS, a powerful mammalian expression vector. Nucleic Acids Research 185322.

Murphy JE, Zhou S, Giese K, Williams LT, Escobedo JA \& Dwarki VJ 1997 Long-term correction of obesity and diabetes in genetically obese mice by a single intramuscular injection of recombinant adeno-associated virus encoding mouse leptin. PNAS 94 13921-13926

No D, Yao TP \& Evans RM 1996 Ecdysone-inducible gene expression in mammalian cells and transgenic mice. PNAS 93 3346-3351.

O'Brien K, Otto K \& Rao RN 1997 Construction and characterization of a one-plasmid system for the controlled expression of genes in mammalian cells by tetracycline. Gene $\mathbf{1 8 4}$ $115-120$.

Owens DR, Zinman B \& Bolli GB 2001 Insulins today and beyond. Lancet 358 739-746.

Pollard H, Toumaniantz G, Amos JL, Avet-Loiseau H, Guihard G, Behr JP \& Escande D $2001 \mathrm{Ca}^{2+}$-sensitive cytosolic nucleases prevent efficient delivery to the nucleus of injected plasmids. Fournal of Gene Medicine 3 153-164.

Pramanik A, Ekberg K, Zhong Z, Shafqat J, Henriksson M, Jansson O, Tibell A, Tally M, Wahren J, Jornvall H, Rigler R \& Johansson J 2001 C-peptide binding to human cell membranes: importance of Glu27. Biochemical and Biophysical Research Communications 284 94-98.

Prud'homme GJ 2000 Gene therapy of autoimmune diseases with vectors encoding regulatory cytokines or inflammatory cytokine inhibitors. Fournal of Gene Medicine 2 222-232.

Rees S, Coote J, Stables J, Goodson S, Harris S \& Lee MG 1996 Bicistronic vector for the creation of stable mammalian cell lines that predisposes all antibiotic-resistant cells to express recombinant protein. Biotechniques 20 102-110.

Rigler R, Pramanik A, Jonasson P, Kratz G, Jansson OT, Nygren P, Stahl S, Ekberg K, Johansson B, Uhlen S, Uhlen M, Jornvall H \& Wahren J 1999 Specific binding of proinsulin C-peptide to human cell membranes. PNAS 96 13318-13323.
Rivera VM, Clackson T, Natesan S, Pollock R, Amara JF, Keenan T, Magari SR, Phillips T, Courage NL, Cerasoli F Jr, Holt DA \& Gilman M 1996 A humanized system for pharmacologic control of gene expression. Nature Medicine 2 1028-1032.

Rivera VM, Ye X, Courage NL, Sachar J, Cerasoli F Jr, Wilson JM \& Gilman M 1999 Long-term regulated expression of growth hormone in mice after intramuscular gene transfer. PNAS 96 8657-8662.

Shaw JA, Delday MI, Hart AW, Docherty HM, Maltin CA \& Docherty K 2002 Secretion of bioactive human insulin following plasmid-mediated gene transfer to non-neuroendocrine cell lines, primary cultures and rat skeletal muscle in vivo. Fournal of Endocrinology 172 653-672.

Spirito F, Meneguzzi G, Danos O \& Mezzina M 2001 Cutaneous gene transfer and therapy: the present and the future. Fournal of Gene Medicine 3 21-31.

Sturtz FG, Cioffi L, Wittmer S, Sonk MJ, Shafer A, Li Y, Leeper NJ, Smith-Gbur J, Shulok J \& Platika D 1998

Tetracycline-regulatable expression vectors tightly regulate in vitro gene expression of secreted proteins. Gene 221 279-285.

Taniguchi H, Fukao K \& Nakauchi H 1997 Constant delivery of proinsulin by encapsulation of transfected cells. Fournal of Surgery Research 70 41-45.

Teiger E, Deprez I, Fataccioli V, Champagne S, Dubois-Rande JL, Eloit M \& Adnot S 2001 Gene therapy in heart disease. Biomedical Pharmacotherapy 55 148-154.

Tripathy SK, Svensson EC, Black HB, Goldwasser E, Margalith M, Hobart PM \& Leiden JM 1996 Long-term expression of erythropoietin in the systemic circulation of mice after intramuscular injection of a plasmid DNA vector. PNAS 93 10876-10880.

Vollenweider F, Irminger JC, Gross DJ, Villa-Komaroff L \& Halban PA 1992 Processing of proinsulin by transfected hepatoma (FAO) cells. Fournal of Biological Chemistry 267 14629-14636.

Wahren J, Ekberg K, Johansson J, Henriksson M, Pramanik A, Johansson BL, Rigler R \& Jornvall H 2000 Role of C-peptide in human physiology. American Fournal of Physiology, Endocrinology and Metabolism 278 E759-E768.

Wang Y, O'Malley BW Jr, Tsai SY \& O'Malley BW 1994 A regulatory system for use in gene transfer. PNAS 91 8180-8184.

Wells DJ 1995 Intramuscular injection of plasmid DNA. Molecular and Cell Biology of Human Diseases Series 5 83-103.

Wolff JA, Ludtke JJ, Acsadi G, Williams P \& Jani A 1992 Long-term persistence of plasmid DNA and foreign gene expression in mouse muscle. Human Molecular Genetics 1 363-369.

Xu ZL, Mizuguchi H, Ishii-Watabe A, Uchida E, Mayumi T \& Hayakawa T 2001 Optimization of transcriptional regulatory elements for constructing plasmid vectors. Gene 272 149-156.

Yanagita M, Hoshino H, Nakayama K \& Takeuchi T 1993 Processing of mutated proinsulin with tetrabasic cleavage sites to mature insulin reflects the expression of furin in nonendocrine cell lines. Endocrinology 133 639-644.

Received in final form 31 January 2003 Accepted 10 February 2003 